\title{
Agriculture in the context of rural development: South-Eastern planning region
}

\author{
Julia Doitchinova ${ }^{1 *}$, and Ivan Kanchev ${ }^{1}$ \\ ${ }^{1}$ University of National and World Economy, Sofia, Bulgaria
}

\begin{abstract}
For 15 years the agrarian business in our country has been developing in a business environment formed mainly by the common agricultural policy. The purpose of the report is to assess this development in the South-East Planning Region and its impacts on the socio-economic development of rural areas and the state of the environment. The report uses quantitative and qualitative methods. They are the basis of mixed research design. Of the quality methods, expert assessment based on a survey and indepth structured interviews with 26 experts at the municipal and district level were applied. Quantitative methods are used to process survey and statistical information on agricultural and rural development in the Southeast planning region. The main results are related to the changes in the production and organizational structure of agriculture and their impact on jobs and employment, the age and qualification structure of the employed, unemployment, migration processes, etc. The characteristics of the applied model of agriculture in terms of the predominant type of farms, the functioning of producer organizations, the transition to the production of quality products with protected geographical indications, etc. are outlined.
\end{abstract}

\section{Introduction}

The common and national agricultural policies since 2007 form the environment in which farms operate and are among the main reasons for the rapid and continuous changes in the production and organizational structures. In practice, the changes intensify the demand for a new model for agricultural development, in which the rural area will also develop sustainably. The main building blocks in recent decades are the production of high-quality products, new short chains with the participation of producers and consumers, organic farming, nature and landscape management by farmers, agritourism and others.

To what extent are these elements and tendencies towards their development characteristic for the model of Bulgarian agriculture? How is the impact of these trends on rural development and viability assessed? To what extent does the changing model of agriculture have a positive effect on the economic, social and economic aspects of rural development? These issues are the subject of research in our country in a number of publications assessing structural changes $[1,2]$, the impacts of environmental agriculture [3, 4], the socio-economic characteristics of rural areas and regional differences in the model of Agriculture [5], etc.

* Corresponding author: juliadoj@unwe.bg 
The purpose of this report is to assess the trends in the development and impacts of rural agriculture in the Southeastern region of Bulgaria.

\section{Literature review}

Loss of fertility and soil erosion, loss of biodiversity, over-fertilization, emerging human health problems caused by water pollution and food quality have been some of the criticisms of the indisputable acceptance of industrial agriculture. These processes with different dimensions accompany the development of rural areas and dynamize the changes in them. Some authors rightly emphasize the different role of the main factor of production in agriculture. For them, industrial agriculture, modernization turns land into a commodity and transforms it into a guarantee for credit operations. Unlike the long-standing traditional approach, the agri-environmental perspective [6] looks at agriculture from an ecosystem perspective, where agriculture and nature contribute to the creation of a sustainable and regenerative ecological system. It consists in the re-appropriation of knowledge by ancestors and in the rediscovery of pre-capitalist traditions and production techniques. To a large extent, there is a process of critical negotiation between traditional knowledge and modern environmental and natural sciences in a more sustainable relationship [7]. According to Van der Ploeg [8], the beginning of the twenty-first century represents a turning point for a new reflection on how land should be reconsidered and the new ways in which neo-rural farmers are recovering. Land is now considered ecological capital and creates conditions for conscious choice of how to use it freedom of action. This created an opportunity to restore local knowledge in rural areas, as well as to implement environmentally friendly farming systems.

According to Van der Ploeg [8], the main question is whether agricultural production should be understood as a commodity system or as a specific form of social and economic practice. In the second dimension, the relationship between the local ecosystem and agricultural practice takes different forms. It is these emerging and preserved traditional forms in rural areas that provide opportunities to create a diverse agricultural ecosystem based on relationships of trust between actors in value chains and sustainable economic and social practices based on long-term rural development.

The link between agriculture and rural areas has led to a reformulation of rural development policy over the last two decades and to the search for agricultural systems and models that help to improve the viability of rural areas. The transformation and adaptability of the agricultural sector and rural economies are key issues for rural development $[9,10$, 11].

\section{Methodology}

The impact of agriculture in the rural area is studied on the basis of statistical data on the characteristics of the region, the production specialization of agriculture and their changes, as well as expert assessment of specialists from the district and municipal administration and the regional office of the National Service for Agriculture. advice in agriculture. For this purpose, in-depth structured interviews were conducted with 26 experts. In them, the characteristics of the area are assessed using a five-point positive Likert scale; the changes that have occurred during the years of our country's membership in the EU and the trends of changes in Bulgarian agriculture and rural areas.

Respondents are from the four districts of the region (NUTS-3) and are distributed as follows: $23.08 \%$ from Burgas, 30.77\% from Sliven; 15.38\% from Stara Zagora and 30.77\% from Yambol. 
The changes at the level of planning region BG34 (NUT 2) and at the level of district (NUT 3) are assessed.

\section{Results}

\subsection{Regional characteristics and development}

The area of the region is $19,799 \mathrm{~km} 2$ and makes up $17.8 \%$ of the country's territory. The agricultural territories are $53 \%$, the forest $42 \%$, the urbanized $4.9 \%$. The region borders on the south with the South-Central region, on the south with the Republic of Turkey, on the east with the Black Sea and on the north with the Northeast and North Central region (figure 1).

On the territory of the South-Eastern region there are 4 districts, 33 municipalities and 683 settlements, of which 38 towns and 645 villages. As of 01.02 .2011 the population of the region is 1078002 people, corresponding to $14.64 \%$ of the total population of the country, and by the end of $2020-1020187$ or about 58 thousand less inhabitants. The largest population is in Burgas district - 409750 people, followed by Stara Zagora districts - 311400 people, Sliven - 182551 people and Yambol -116486 people. The data show a declining population trend in South-Eastern region, which follows the pace of the country.

The average population density in the South-Eastern region is $54.4 \mathrm{~h} / \mathrm{sq} . \mathrm{km}$ in 2011 (significantly lower than the national average $-66.34 \mathrm{~d} / \mathrm{sq} . \mathrm{km}$ ) and decreases to $51.52 \mathrm{in}$ 2020. On the territory of The largest cities in the region are Burgas and Stara Zagora, the medium-sized cities (between 30,000 and 100,000) are Sliven, Yambol and Kazanlak.

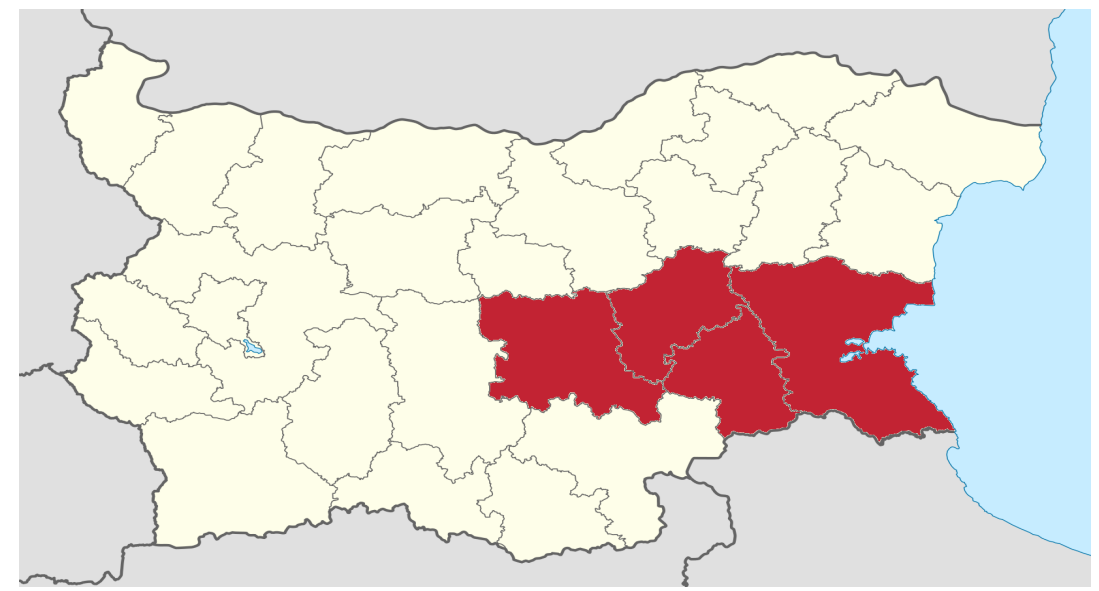

Fig. 1. Map of Republic Bulgaria

The gross domestic product per capita is $57.15 \%$ of the national average. It is highest in the districts of Stara Zagora - 8321.91 euros and Burgas - 6870.33 euros. The lowest values of the gross domestic product per capita are in the districts of Sliven (EUR 4156.87) and Yambol (EUR 5185.60). GDP per capita in Sliven district is almost 2 times lower than the national average. (Table 1).

The relative share of poor people is close to the national average - $27 \%$ for the southeastern region and $26.5 \%$ on average for the country. In the districts of Sliven and Burgas, the relative share of the poor people is $31.3 \%$ and $29 \%$, respectively.

Table 1. Social-economic indicators of South-Eastern region 


\begin{tabular}{|c|c|c|c|c|c|}
\hline Regions & $\begin{array}{c}\text { GDP per } \\
\text { capita of } \\
\text { population } \\
\text { (euros) }\end{array}$ & $\begin{array}{c}\text { Share of the } \\
\text { poor in relation } \\
\text { to the poverty } \\
\text { line in the } \\
\text { country in } 2017 \\
\text { (\%) }\end{array}$ & $\begin{array}{c}\text { Share of } \\
\text { agriculture } \\
\text { in gross } \\
\text { value added } \\
\mathbf{( \% )} \text { by } \\
\text { districts }\end{array}$ & $\begin{array}{c}\text { Share of } \\
\text { districts in } \\
\text { the national } \\
\text { gross value } \\
\text { added of } \\
\text { agriculture } \\
\text { (\%) }\end{array}$ & $\begin{array}{c}\text { Share of } \\
\text { agriculture } \\
\text { in } \\
\text { employment } \\
\text { (\%) }\end{array}$ \\
\hline Burgas & 6870.33 & 29.0 & 4.02 & 4.93 & 20.63 \\
\hline Sliven & 4156.87 & 31.3 & 8.53 & 2.86 & 32.96 \\
\hline Stara Zagora & 8321.91 & 26.9 & 3.80 & 4.34 & 17.22 \\
\hline Yambol & 5185.60 & 22.2 & 11.72 & 3.13 & 32.34 \\
\hline $\begin{array}{c}\text { Yugoiztochen } \\
\text { region }\end{array}$ & 5017.38 & 27.0 & 5.14 & 15.26 & 22.86 \\
\hline Bulgaria & 8779.02 & 26.5 & 3.75 & 100 & 18.86 \\
\hline
\end{tabular}

Source: $[12,13]$

A significant part of the agricultural production is produced in the studied area. For 2019 it is $15.26 \%$ of the production in Bulgaria. By districts the highest is the relative share of production in the districts of Burgas (4.93\%) and Stara Zagora (4.34 5), and the lowest in the districts of Sliven (2.86\%) and Yambol (3.13\%). At the same time, agriculture has the highest share of gross value added in these areas - $11.72 \%$ in Yambol and $8.53 \%$ in Sliven. Significantly less is its importance for the economy of Burgas and Stara Zagora - respectively $4.02 \%$ and $3.80 . \%$

According to National Statistics Institute data, the region has $4.7 \%$ unemployment rate for 2020 , compared to $5.1 \%$ on average for Bulgaria. By districts the highest unemployment is in Yambol and Sliven - respectively $7.2 \%$ and $6.9 \%$.

With the exception of Stara Zagora district, the relative share of employees in agriculture is high in the other districts. Most employed are in Sliven and Yambol - respectively 32.96\% and 32.34\%, followed by Burgas (20,63 \%) and Stara Zagora (17,22 \%).

\subsection{Product structure}

The natural-climatic and soil conditions in the South-Eastern region are favorable for the development of a great variety of agricultural crops. Despite the usual annual changes in areas and production, the region is usually in first or second place in the country for the production of major crops. Data from the distribution of arable land show a very high presence of cereals and oilseeds. Together they occupy $85.15 \%$ of the arable land (Figure 2). The relative share of vegetables is $5.62 \%$, and according to this indicator the region ranks third in the country. 


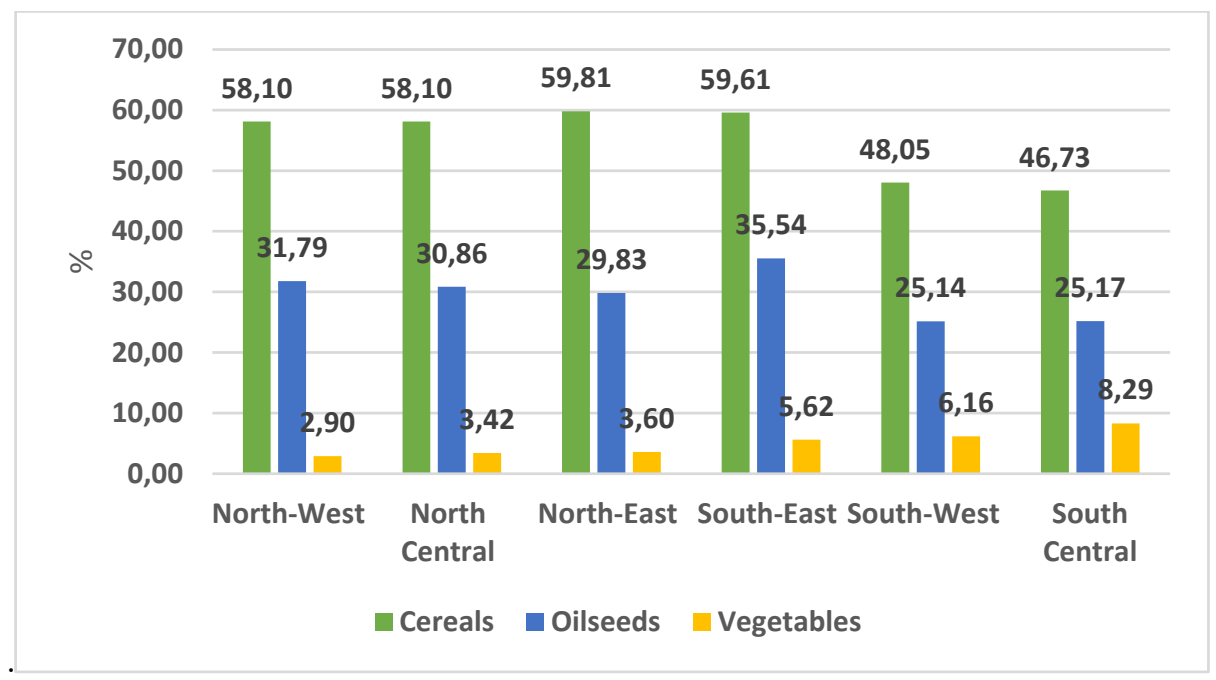

Fig. 2. Relative shares of main crops in the structure of arable land [14]

According to the latest agricultural report, the leading place in fruit production is occupied by the Southeast region with $26.3 \%$ of the total production for the year, followed by the South-Central region with $21.4 \%$. In the South-Eastern region the production of peaches $(44.8 \%)$ and cherries (39\%) is concentrated, and in the South-Central region - that of cherries $(40.4 \%)$, apples $(37.3 \%)$ and plums and junipers $(23), 8 \%)$. In the North Central region, $85.8 \%$ of the apricots for the country are produced.

The region is a major producer of grapes and products from its processing. In recent years, it produces the largest amount of grapes and wine in the country, part of which is high quality and regional.

The southeastern region ranks second in the country in terms of milk production, number of cattle, number of sheep and third for the other main livestock productions.

\subsection{Structure of agricultural holdings}

Significant changes in the product structure are accompanied by changes in organizational structures. The data of the Agrostatistics Directorate of the Ministry of Agriculture, Food and Forestry for 2010 and 2016 show that $30.23 \%$ have completed their activities for the sevenyear period. This is the lowest value for the country and is significantly less than in the Northwest (62\%), Northeast (55\%) and others. At the same time, the average size of utilized agricultural land per farm increased from 13.42 ha in 2010 to 29.57 ha in 2016 or 2.2 times.

The production structure of the country has its influence on the structures of farms by economic size and on the distribution of production volume by farms with different production volume. In all regions of the country there is a significant number of very small farms (with an economic size below 2000 euros), which produce a small relative share of the standard production volume. In the South-East region, $48.07 \%$ of farms are very small (Figure 3 ) and produce $1.65 \%$ (Figure 4 ). At the other pole are $2.17 \%$ of farms with an economic size of over 250,000 euros, which create $60.50 \%$ of the standard production volume. 


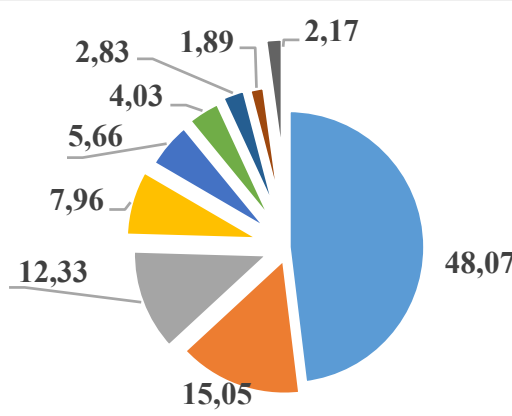

$$
\begin{aligned}
& =<\mathbf{2 0 0 0} \\
& =>\mathbf{8 0 0 0}<\mathbf{1 5 0 0 0} \\
& ->=\mathbf{5 0 0 0 0}<\mathbf{1 0 0 0 0 0}
\end{aligned}
$$$$
->=2000<4000
$$$$
\text { - }>=15000<25000
$$$$
\text { - }>=100000<250000
$$

$$
\begin{aligned}
& ->=4000<8000 \\
& ->=\mathbf{2 5 0 0 0}<\mathbf{5 0 0 0 0} \\
& ->=\mathbf{2 5 0 0 0 0}
\end{aligned}
$$

Fig. 3. Structure of agricultural holdings in the South-East planning region by economic size [12]

Unlike the other regions of the country, in the South-East the importance of the farms in the medium-sized economic groups is greater.

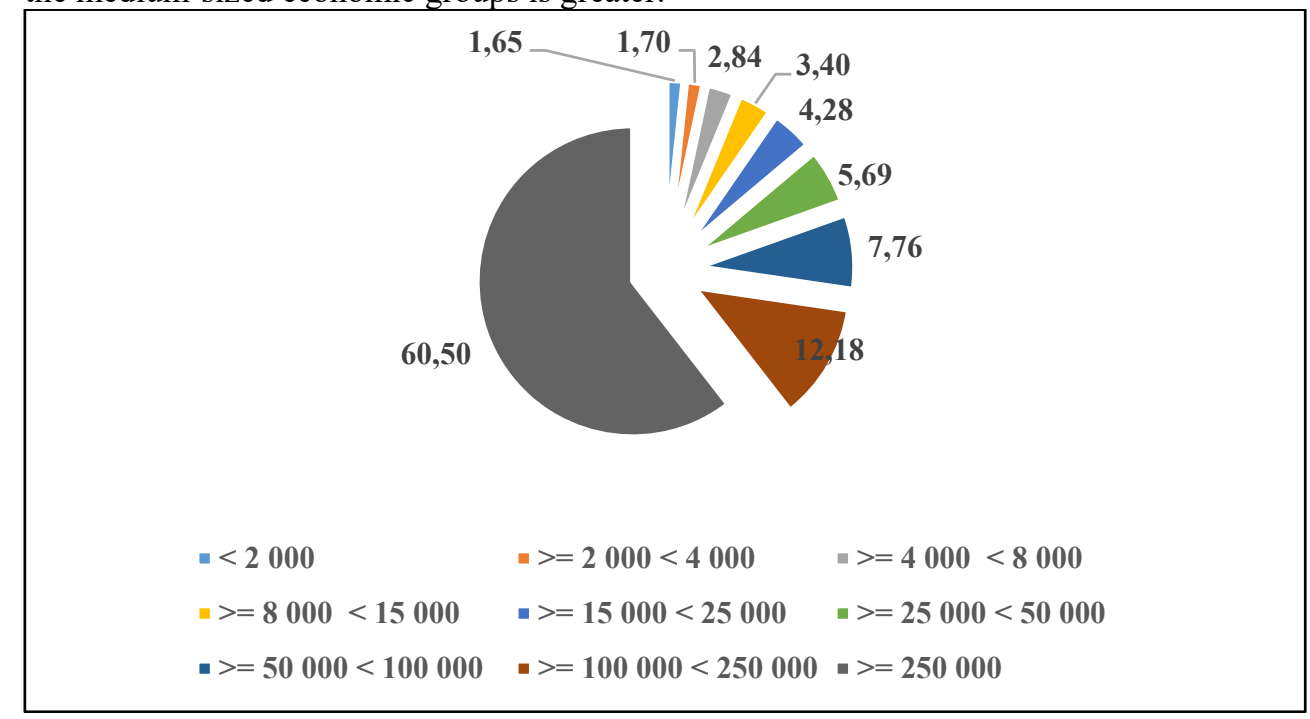

Fig. 4. Structure of the standard production volume in the South-East region, produced by farms of different economic size [12]

\subsection{Regional analysis}

Despite the different importance of agriculture for the economy of the four districts in the Southeast region (Table 1), experts from the district directorates, municipal services and district offices of the National Agricultural Advisory Service appreciate it very highly. The average score for the region is 4.54 on a five-point scale (Figure 5). The highest score is in Stara Zagora district (4.75), followed by Sliven (4.64), Yambol (4.5) and Burgas (4.33).

Estimates are lower about the opportunities for agriculture to generate income. At 3.85 on average for the region, they range between 3.50 and 4.13. Agriculture as a source of jobs is rated the lowest - 3.17 (in Burgas) and the highest - 4.38 (in Sliven). 
The lowest is the assessment of the statement about the positive impact of agriculture on the environment. The experts' estimates range from 3.17 (Burgas) to 3.75 (Stara Zagora) compared to an average of 3.38 for the region.

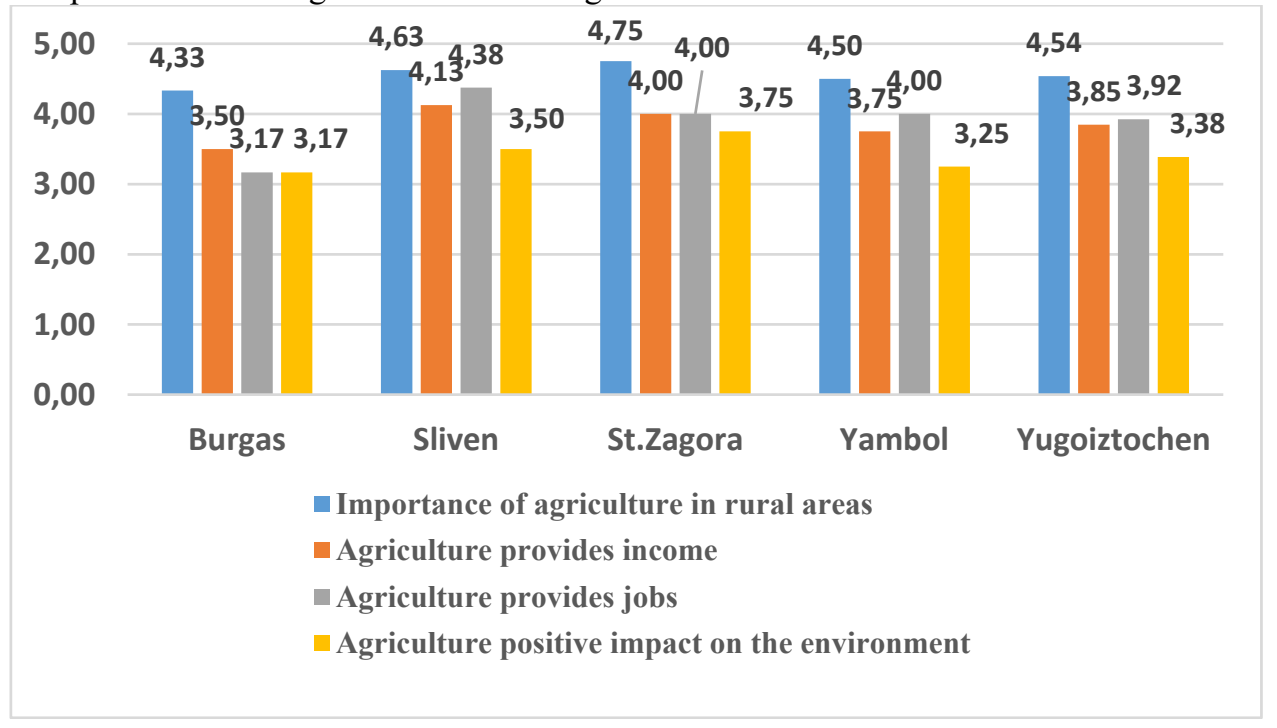

Fig. 5. Experts evaluation of importance of agriculture per districts

Source: Own study

One of the reasons for the differences in the assessments of the importance of agriculture and its social and environmental aspects is the specialization of production in the areas. It is estimated in the range from 3.6 (Burgas) to 3.86 (Yambol). In two of the districts (Sliven and Yambol) the experts believe that other productions can be developed in the region, which will bring higher income to the farmers. In general, for the region the assessment of the production specialization is 3.71 , and of the opportunities for other productions and higher incomes - 3.87 (Table 2).

Insufficient irrigated areas and labor force are highly supported as reasons for the current specialization. Insufficient irrigated areas are estimated at an average of 3.5, but in the range of 3.25 (Stara Zagora) to 3.83 (Burgas). Insufficient labor force is supported to an even higher extent - by 4.5 in Sliven district, 4.17 in Burgas, 3.75 in Yambol and 3.25 in Stara Zagora (Table 2).

Are the changes stimulated by the Common Agricultural Policy towards the production of high quality products, organic products, towards the application of agri-environmental schemes, etc. being implemented in our country? When testing these changes, different degrees of evaluation are observed. The highest score in the Southeast planning region was given to the tendency to increase the number of farms that produce high quality products. The average expert assessment is 3.73 (Table 3), ranging from 4.0 (Burgas and Sliven) to 3.67 (Stara Zagora and Yambol).

The second most important assessment is for the increase of agricultural holdings that apply agri-environmental practices. It is the highest in Stara Zagora (4.0) and Yambol (3.71), and the lowest in Sliven (3.5)

Table 2. Experts evaluation of production specialization

\begin{tabular}{|c|c|c|c|c|}
\hline Districts & $\begin{array}{c}\text { Specialization } \\
\text { of the farms is }\end{array}$ & $\begin{array}{c}\text { The } \\
\text { conditions } \\
\text { are suitable }\end{array}$ & $\begin{array}{c}\text { Insufficient } \\
\text { irrigated areas are } \\
\text { the reason for the }\end{array}$ & $\begin{array}{c}\text { Labor } \\
\text { shortages are a } \\
\text { reason for }\end{array}$ \\
\hline
\end{tabular}




\begin{tabular}{|c|c|c|c|c|}
\hline & $\begin{array}{c}\text { appropriate for } \\
\text { the rural area }\end{array}$ & $\begin{array}{c}\text { for higher } \\
\text { income } \\
\text { industries }\end{array}$ & $\begin{array}{c}\text { reduction of some } \\
\text { productions }\end{array}$ & $\begin{array}{c}\text { limiting labor- } \\
\text { intensive } \\
\text { industries }\end{array}$ \\
\hline Burgas & 3.6 & 3.5 & 3.83 & 4.17 \\
\hline Sliven & 3.67 & 4.0 & 3.57 & 4.5 \\
\hline Stara Zagora & 3.67 & 3.5 & 3.25 & 3.25 \\
\hline Yambol & 3.86 & 4.25 & 3.75 & 3.75 \\
\hline $\begin{array}{c}\text { South-East } \\
\text { Region }\end{array}$ & 3.71 & 3.87 & 3.5 & 4.15 \\
\hline
\end{tabular}

Source: Own study

Next, the tendency for growth of organic farms is supported. The score for the area is 3.04. It is highest in Sliven district (3.67), followed by Burgas (3.16), Stara Zagora (2.75) and Yambol (2.67).

Table 3. Evaluation of the trends of development of agriculture

\begin{tabular}{|c|c|c|c|c|}
\hline Districts & $\begin{array}{c}\text { The number of } \\
\text { farms that aim at } \\
\text { producing better } \\
\text { quality products } \\
\text { is increasing }\end{array}$ & $\begin{array}{c}\text { The number } \\
\text { of organic } \\
\text { farms is } \\
\text { growing }\end{array}$ & $\begin{array}{c}\text { The number of } \\
\text { farmers } \\
\text { applying agri- } \\
\text { environment } \\
\text { practices is } \\
\text { increasing }\end{array}$ & $\begin{array}{c}\text { The number of } \\
\text { farms that } \\
\text { diversify their } \\
\text { activities with } \\
\text { tourist } \\
\text { activities is } \\
\text { increasing }\end{array}$ \\
\hline Burgas & 4.0 & 3.16 & 3.6 & 2.5 \\
\hline Sliven & 4.0 & 3.67 & 3.5 & 2.17 \\
\hline Stara Zagora & 3.67 & 2.75 & 4.0 & 3.0 \\
\hline Yambol & 3.67 & 2.67 & 3.71 & 1.75 \\
\hline South-East & 3.73 & 3.04 & 3.67 & 2.25 \\
\hline Region & & & & \\
\hline
\end{tabular}

Source: Own study

Lowest is the support of the tendency to diversify with tourist activity - the average for the district is 2.25, in the range of 3.0 in Stara Zagora to 1.75 in Yambol.

The number of agricultural holdings that aim to feed households is growing. This trend is assessed by 4.33 by experts in Stara Zagora, by 3.88 in Sliven, followed by 3.4 in Yambol and 3.33 in Burgas (Table 4). The tendency for farms to diversify is not supported. The estimates are higher only in Burgas and Sliven. At the same time, the tendency for increase of the holdings that make direct sales in Burgas and Sliven districts is highly rated (with 4), and with 3.67 in the other two districts.

According to the experts from Yambol district, the number of farms that process their products is growing (3.67). Such a trend is not observed in Stara Zagora district (1).

Table 4. Evaluation of the trends of development of agriculture 


\begin{tabular}{|c|c|c|c|c|}
\hline Districts & $\begin{array}{c}\text { The number of } \\
\text { farms aiming at } \\
\text { providing } \\
\text { livelyhood to the } \\
\text { household has } \\
\text { increased }\end{array}$ & $\begin{array}{c}\text { The number of } \\
\text { farms that have } \\
\text { diversified their } \\
\text { activities with non- } \\
\text { agricultural } \\
\text { activities increased }\end{array}$ & $\begin{array}{c}\text { The } \\
\text { number of } \\
\text { holdings } \\
\text { making } \\
\text { direct sales } \\
\text { has } \\
\text { increased }\end{array}$ & $\begin{array}{c}\text { The number } \\
\text { of farms } \\
\text { processing } \\
\text { agricultural } \\
\text { products } \\
\text { increased }\end{array}$ \\
\hline Burgas & 3.33 & 3 & 4 & 2.67 \\
\hline Sliven & 3.88 & 2.33 & 4 & 2.83 \\
\hline Stara Zagora & 4.33 & 0 & 3.67 & 1 \\
\hline Yambol & 3.4 & 2 & 3.67 & 3.67 \\
\hline South-East & 3.74 & 1.46 & 3.89 & 2.84 \\
\hline Region & & \multicolumn{3}{|l}{} \\
\hline
\end{tabular}

Source: Own study

\section{Conclusion}

The assessment of the development of agriculture in the South-Eastern region gives grounds for the following more important conclusions:

- Agriculture is well developed, and a large number of different products are grown. The region is a major producer of grapes, peaches, sunflowers, cereals, livestock products, etc.;

- Although the region is in the top ten of the EU's industrialized regions, the importance of agriculture for rural development is highly valued;

- Compared to other regions in the country, the number of agricultural holdings is decreasing at a slower pace;

- The production specialization of the farms is assessed with values close to the average, as according to the experts the insufficient irrigated areas and the insufficient labour force are the main reasons for limiting the production of fruits and vegetables;

- The changes in the strategies of agricultural holdings stimulated by the CAP are relatively slow, which is why they are assessed by experts with values close to the average of the five-point scale. The trends for increasing the number of farms that make direct sales, produce quality products and apply agri-environmental schemes are highly valued;

Despite declining economic importance, the agricultural sector continues to play a crucial role in development, especially in low-income regions and a significant proportion of those living below the poverty line. This requires the implementation of regional policies that stimulate the use of the objective advantages of rural areas and targeted efforts of all stakeholders to improve the market and institutional structure of agricultural holdings.

The research leadings to these results has received funding from the Bulgarian Science Fund - project \$Sustainable multifunctional rural areas: rethinking agricultural models and systems with increased requirements and limited resources\$(2017-2020).

\section{References}

1. J. Doitchinova, A. Miteva, Agriculture and rural development: paths of change and consequences, in Scientific Papers: Series "Management, Economic Engineering in Agriculture and rural development", 20 (3), 207-214 (2020) 
2. J. Doitchinova, Z. Stoyanova, Bul. JAEM, 4, p.66-73 (2020)

3. Z. Stoyanova, H. Harizanova, AGROFOR Intern. J., 4(1), 111-118 (2019)

4. H. Harizanova-Bartos, Z. Stoyanova, Impact of agriculture on air pollution, in CBU International Conference Proceedings 6, 1071-1076 (2018)

5. J. Doitchinova J., A. Miteva, D. Zaimova, Determinants and directions of the transition from traditional to sustainable agriculture: the Bulgarian case, in Proceedings of International conference on innovations in science and education, Prague, Czech Republic, 75-80 (2019), www.iseic.cz

6. S. R. Gliessman, Agroecology: the ecology of sustainable food systems, (Boca Raton: CRC press, 2014)

7. B. Snipstal, Can. Food Stud., 2(2), 164-173 (2015), doi: 10.15353/cfsrcea.v2i2.132

8. J. D. Van Der Ploeg, J. Peasant Stud., 37(1), 1-30 (2010)

9. L. G. Horlings, T.K.Marsden, Eur. Urban Reg. Stud., 21 (1), 4-20 (2014)

10. European Commission, Sustainable Agriculture, Forestry and Fisheries in the Bioeconomy: a Challenge for Europe, Standing Committee on Agricultural Research (SCAR), Brussels (2015)

11. S. Peter, K. Knickel, Renewable energy transitions e lessons learned from rural pilot regions and communities in southwestern Germany, In: Wilcox, A., Vinall, S. (Eds.), Social and Technological Transformation of Farming System, Harper Adams University, 135 (2016)

12. Ministry of Agriculture, Foods and Forestry, Agro statistics, Sofia (2018)

13. National Statistical Institute, Sofia (2020)

14. Ministry of Agriculture, Foods and Forestry, Agro statistics, Sofi, (2020) 